\title{
THE LINGUISTIC ASPECTS OF THE UKRAINIAN EDUCATIONAL POLICY
}

\section{István Csernicskó \\ TransCarpathian Hungarian College named after Ferenc Rákóczi II}

\begin{abstract}
In accordance with the Constitution and the Law of Ukraine on Languages, de jure Ukraine is a monolingual state. However, Ukraine de facto is multilingual. The Ukrainian state language policy would like to solve the discrepancy between the de jure and the de facto situation in such a way that the language situation of the country should be harmonized with the codified legal situation. Namely, the unspoken aim is to turn Ukraine into a practically monolingual, a de facto Ukrainian-speaking state. Education is seen as ideal means to achieve these aims. At the given paper this will be supported by a lot of evidence. Thus, Ukraine, instead of fostering the present-day ethnic and linguistic diversity, pursues the state model that is colourful from the ethnic point of view but homogeneous linguistically. The data presented in this study highlight the fact that this process involves heavy losses also for the Hungarian minority in Transcarpathia.
\end{abstract}

Keywords: Ukrainian language politics, educational policy, Hungarians in Transcarpathia

In accordance with the Constitution and the Law on Languages Ukraine is (de jure) a monolingual state (see Beregszászi and Csernicskó 2003, 2007). However, Ukraine de facto is multilingual. In this paper the complexity of the Ukrainian multilingualism will be introduced and at the same time I will demonstrate the way how the Ukrainian power elite tries to eradicate linguistic heterogeneity, how it endeavours to achieve harmony between the de facto and de jure situation. Finally, I will show the role education plays in this process.

Some experts (e.g. Arel and Khmelko 1996, Gritsenko et al. 2001, Khmelko 2004) maintain that Ukraine's population is made up of three lingua-ethnic groups:

1) Ukrainian speaking Ukrainians (about $40-45 \%$ of the country's population); 
2) Russian speaking Ukrainians (about 30-34\% of the country's population);

3) Russian speaking Russians (about 20\%).

However according to the 2001 national census (which focussed not only on Ukrainian and Russian populations, but also on other small linguistic groups) the population of Ukraine can be divided into the following groups on the basis of people's native language:

a) People who speak Ukrainian as their native language, including:

- Ukrainians (by nationality) whose native language is Ukrainian (85\% of those who claimed to be Ukrainian);

- Russians whose native language is Ukrainian (4\% of those who claimed to be Russian);

- National minorities whose native language is Ukrainian (e.g. $71 \%$ of the Poles, $42 \%$ of the Slovaks who live in Ukraine);

b) People who speak Russian as their native language, including:

- Russians whose native language is Russian (96\% of those who claimed to be Russian);

- Ukrainians whose native language is Russian (15\% of Ukrainians);

- National minorities whose native language is Russian (e.g. $62 \%$ of the Byelorussians);

c) National minorities whose ethnicity and native language are the same (e.g. 95\% of the Hungarians, 92\% of the Romanians);

d) National minorities who speak the native language of another minority group (e.g. in Transcarpathia $62 \%$ of the Roma consider Hungarian to be their native language (see Molnar 2004: 120-121), this group constitutes 18\% of all Roma in Ukraine). 
Table 1.The population of Ukraine according to native language and ethnicity (based on the data from the 2001 national census).

\begin{tabular}{|c|c|c|}
\hline ETHNICITY AND NATIVE LANGUAGE & $\begin{array}{l}\text { NUMBER OF } \\
\text { PEOPLE }\end{array}$ & $\%$ \\
\hline $\begin{array}{l}\text { Ukrainians (by ethnicity) whose native language } \\
\text { is Ukrainian }\end{array}$ & 31970728 & 66.27 \\
\hline Russians whose native language is Ukrainian & 328152 & 0.68 \\
\hline $\begin{array}{l}\text { National minorities whose native language is } \\
\text { Ukrainian }\end{array}$ & 278588 & 0.58 \\
\hline $\begin{array}{l}\text { TOTAL NUMBER OF THOSE WHOSE } \\
\text { NATIVE LANGUAGE IS UKRAINIAN }\end{array}$ & 32577468 & 67.53 \\
\hline Russians whose native language is Russian & 7993832 & 16.57 \\
\hline Ukrainians whose native language is Russian & 5544729 & 11.49 \\
\hline $\begin{array}{l}\text { National minorities whose native language is } \\
\text { Russian }\end{array}$ & 735109 & 1.52 \\
\hline $\begin{array}{lll}\text { TOTAL NUMBER OF THOSE WHOSE } \\
\text { NATIVE LANGUAGE IS RUSSIAN }\end{array}$ & 14273670 & 29.59 \\
\hline $\begin{array}{l}\text { National minorities whose ethnicity and native } \\
\text { language are the same }\end{array}$ & 1129397 & 2.34 \\
\hline $\begin{array}{l}\text { National minorities who speak the native language } \\
\text { of another minority group as their native language }\end{array}$ & 260367 & 0.54 \\
\hline $\begin{array}{l}\text { TOTAL NUMBER OF THOSE WHO SPEAK } \\
\text { MINORITY LANGUAGES }\end{array}$ & 1389764 & 2.88 \\
\hline $\begin{array}{l}\text { TOTAL NUMBER OF SPEAKERS IN } \\
\text { UKRAINE }\end{array}$ & 48240902 & 100 \\
\hline
\end{tabular}

If we take into consideration native language and ethnicity census data (Fig. 1) the following statements can be made:

a) The percentage of people whose ethnicity is Ukrainian is higher than the percentage of people who speak Ukrainian;

b) The percentage of people who speak Russian is higher than the percentage of people who consider themselves to be ethnically Russian;

c) Ethnic diversity is greater in Ukraine than linguistic diversity because a number of minority groups have begun to speak Russian or (less frequently) Ukrainian. 


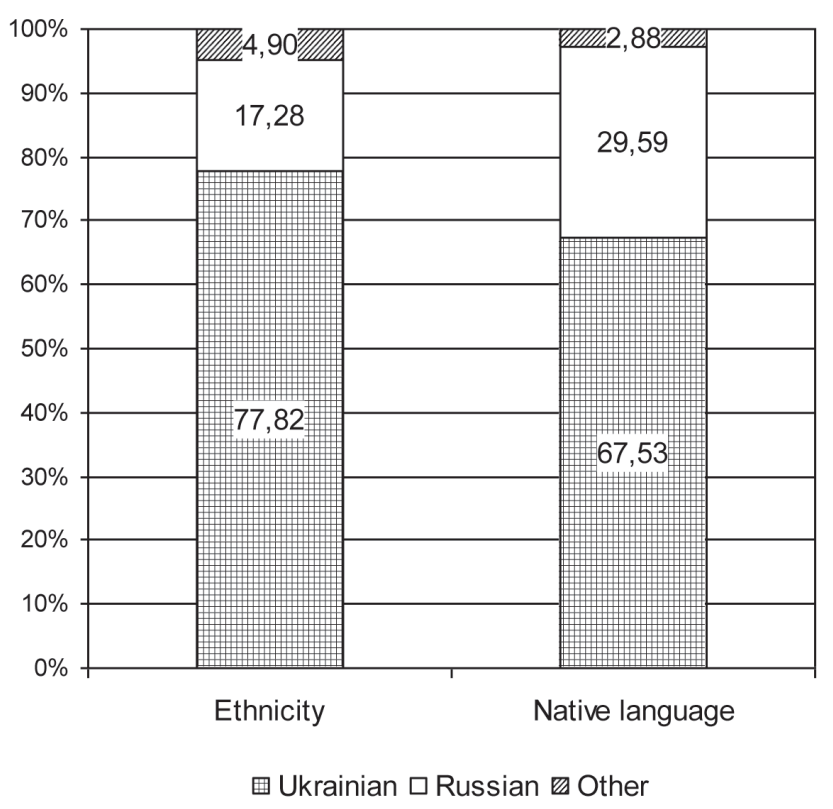

Figure 1. The population of Ukraine according to native language and ethnicity (2001 national census data).

If we concentrate on one more aspect besides ethnicity and native language, the linguistic picture of Ukraine becomes more complicated. This aspect is the percentage of pupils studying in different languages in the country. In the 2003/2004 academic year $75.05 \%$ of the Ukrainian pupils studied in schools with Ukrainian as the language of instruction, $23.89 \%$ in schools with Russian medium, and no more than $1.06 \%$ studied in schools where the language of instruction was other than Ukrainian or Russian.

This means that:

a) More pupils study in schools with Ukrainian as the language of instruction than the number of people who speak Ukrainian as their native language, but fewer than the number of people who consider themselves Ukrainian by ethnicity;

b) Fewer pupils study in schools with Russian as the language of instruction than the percentage of those whose native language is Russian in the country, but considerably more than the percentage of people with Russian ethnicity; 
c) Even though the percentage of those who are not Ukrainian/Russian is about five percent and the percentage of those who speak minority languages as their native language is about three percent, only one child in a hundred can learn in a school where the medium of instruction is not Ukrainian or Russian (see Fig. 1).

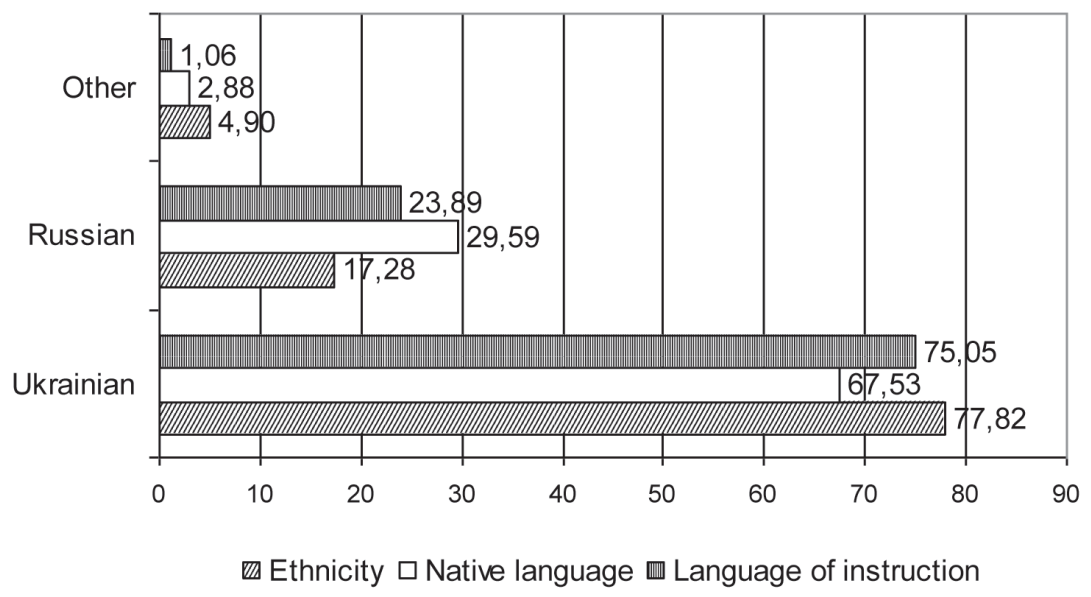

Figure 2. The coincidence of ethnicity, native language and the language of instruction in the population of Ukraine, based on the 2001 census data.

Nevertheless, it is widely believed that the census results over-simplify the real linguistic landscape (e.g. Kotygorenko 2007). If we take into account not only the census data, but also data of a sociolinguistic survey based on a national representative sample, then the language make-up of the population will show a very different picture. Panina (2005) conducted sociolinguistic researches between 1994 and 2005 on an 1800-strong representative sample of the adult population of Ukraine. Of the sample, $64.3 \%$ consider Ukrainian to be their mother tongue, while for $34.1 \%$ it was Russian, and 1.5\% chose other languages in 2005 (Panina 2005: 68).

Another sociolinguistic research between 1991 and 2003 examined continuously the usage of languages among the adult population of Ukraine, based on a representative sample from approximately 173 thousand interviews, which were conducted to yield comparable data (cf. Khmelko 2004). This study revealed 
that, from the point of view of ethnicity and native language, we can find different language situations in the different regions of Ukraine. In the five large regions which the author identified, the percentage of those who speak Ukrainian or Russian as their native language, or use a contact variety of the two languages (the so called surzhyk $k^{1}$ ) is very high (see Table 2).

According to this model there are not only three linguistic groups in Ukraine (whose native language is Ukrainian, whose native language is Russian, whose native language is a minority language) as 2001 national census shows us, but we must deal with an additional group: people whose native language is surzhyk. If we look at the linguistic picture based on the sociological survey, we may say that peoples who speak Russian as their native language comprise the relative majority in comparison to peoples with Ukrainian as their native language (see Fig. 3).

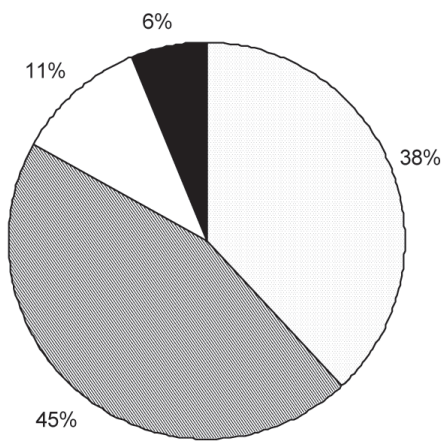

$\square$ Ukrainian as native language $\square$ Russian as native language

$\square$ Surzhyk as native language

- Other language

Figure 3. The distribution of the adult population of Ukraine according to their native language in $2003(\mathrm{~N}=22.462)$.

Source: Khmelko (2004)

\footnotetext{
Surzhyk (суржик) is a mixed language of Ukrainian and Russian (Lenets 2000; Bilaniuk 2003, 2004, 2005), its prestige is low and it often becomes the bane of the purist Ukrainian linguists, who associate low education and dual identity with the speakers of surzhyk (Bilaniuk 2004). This fact is reflected by the entry of surzhyk in the encyclopaedia of the Ukrainian language and some other writings concerning the linguistic situation of the country (see Lenets 2000 or e.g. Lozinskyi 2006: 225-226).
} 
Table 2. The distribution of the adult population of Ukraine according to their ethnicity and native language in different regions in $2003(\mathrm{~N}=22.462)$.

Source: Khmelko (2004)

\begin{tabular}{|c|c|c|c|c|c|c|}
\hline & \multicolumn{5}{|c|}{ Region } & \multirow[b]{2}{*}{$\begin{array}{c}\text { Total } \\
(\%)\end{array}$} \\
\hline & $\begin{array}{l}\text { West }^{2} \\
(\%)\end{array}$ & $\begin{array}{c}\text { Middle- } \\
\text { West }^{3} \\
(\%)\end{array}$ & $\begin{array}{c}\text { Middle- } \\
\text { East }^{4} \\
(\%)\end{array}$ & $\begin{array}{l}\text { South }^{5} \\
(\%)\end{array}$ & $\begin{array}{c}\text { East }^{6} \\
(\%)\end{array}$ & \\
\hline $\begin{array}{l}\text { Ukrainians } \\
\text { whose } \\
\text { native } \\
\text { language } \\
\text { is } \\
\text { Ukrainian }\end{array}$ & 91.7 & 59.3 & 30.8 & 5.3 & 3.6 & 38.5 \\
\hline $\begin{array}{l}\text { Ukrainians } \\
\text { whose } \\
\text { native } \\
\text { language } \\
\text { is Surzhyk }\end{array}$ & 1.5 & 13.0 & 20.6 & 11.3 & 8.3 & 10.7 \\
\hline $\begin{array}{l}\text { Ukrainians } \\
\text { whose } \\
\text { native } \\
\text { language } \\
\text { is Russian }\end{array}$ & 1.3 & 17.2 & 33.5 & 40.0 & 48.6 & 28.0 \\
\hline $\begin{array}{l}\text { Russians } \\
\text { whose } \\
\text { native } \\
\text { language } \\
\text { is Russian }\end{array}$ & 1.5 & 5.8 & 11.1 & 31.1 & 34.1 & 16.9 \\
\hline
\end{tabular}

2 The West region consists of Volyn, Rivne, Lviv, Ivano-Frankivsk, Ternopil, Zakarpats'ka and Chernivci counties.

3 The Middle-West region is devided into Khmelnytsk, Zhytomyr, Vynnitsia, Kirovohrad, Cherkasy, Kyiv counties and Kyiv City.

4 We can find Dnyipropetrovsk, Poltava, Sumy and Chernihiv counties in the Middle-East region.

5 The components of the South region are the following: Odessa, Mykolaiv, Kherson, Zaporizhzhia counties and Autonomous Republic of Crimea with the City of Sevastopol.

6 Kharkiv, Donetsk and Luhansk counties are situated in the East region. 
Based on the above-mentioned facts, it is not surprising that some analysts say that in Ukraine not two but three languages are used: Ukrainian, which has gained the status of the state language, Russian as the postcolonial heritage language (cf. e.g. Masenko 2004), and the contact version of the two: Surzhyk (cf. e.g. Berezovenko 2002). The mentioned three languages are widely used by the speakers and compete with each other on the virtual market. Bilaniuk (2004) had worked out the typology of Surzhyk and, on the basis of historical, sociological and ideological factors, established the following types: a) urbanized peasant Surzhyk; b) village dialect-Surzhyk; c) Sovietized-Ukrainian Surzhyk; d) urban bilinguals' Surzhyk; e) post-independence Surzhyk.

Radchuk's (2002a, 2002b) survey showed that, on the lexical level, there is only a $10 \%$ difference between Standard Ukrainian and Standard Russian. He also stated that the vocabulary of Surzhyk differs approximately $10 \%$ from the standard versions of Ukrainian and Russian, so it may become an independent language. Nevertheless, the linguistic description of Surzhyk is not completed; this contact version is a good example of the historical aspect, the intensity and the expansion of the close Ukrainian-Russian linguistic contacts.

In addition to all this, according to the results of Khmelko's survey (2004: 3-15) in 2001 12.4\% of 5226 adult Ukrainian citizens regarded Ukrainian and Russian as their two native languages.

As the given data show us Ukraine obviously is not monolingual, however many researcher regard the existing multilingualism as a problem (see e.g. Lozinskyi 2006: 217). The Ukrainian state language policy would like to solve the discrepancy between the de jure and the de facto situation by harmonising the language situation of the country with the codified legal situation. Namely, the unspoken aim is to turn Ukraine into a practically monolingual, a de facto Ukrainian-speaking state. Education is seen as an ideal means to achieve these aims. The examples below, in our opinion, prove that educational policy is used as a means to achieve the goals of nation and language policy:

1. In the final statement of a council meeting in the Ministry of Education and Science where the low level of teaching the official language in ethnic schools was the key issue of the discussion, the increasing number of schools with Ukrainian as the medium of instruction was emphasized as a positive linguistic phenomenon. ${ }^{7}$

For the confirmation approved by the council meeting see the official website of the Ministry of Education and Science of Ukraine. (http://www.mon.gov.ua/ newstmp/2008/20_03/doc.doc). 
There was no mention of strengthening minority languages as the languages of instruction or teaching them as subjects in schools. The state programme ${ }^{8}$ responsible for improving the level of teaching the Ukrainian language also considers positively the rising number of schools with Ukrainian as the language of instruction.

2. According to paragraph (8) of the statute N 244/2008 published by the President of Ukraine on March 20, 2008 about the improvement of the quality of education in Ukraine, minorities' educational demands should be satisfied in such a way that some subjects should be taught in Ukrainian in the minority schools. The situation of minority language education is not discussed in this document either.

3. Statute $\mathrm{N} 461$ published by the Minister of Education, Ivan Vakarchuk on May 26, 2008 put into force a departmental programme (for the years between 2008 and 2011) ${ }^{9}$ for ethnic schools in order to improve the teaching of Ukrainian language. According to the action plan, from September 1, 2008 in the 5th grade of nationality schools the subject History of Ukraine should be taught bilingually: in the native language and in the state language (at the expense of the optional lessons). In the 6th grade the subject should be taught only in Ukrainian (from September 1, 2009). In the 6th grade geography and in the 7th grade mathematics should be taught bilingually, and then in the next grade they should only be taught in the state language. The long-range aim of this educational model is to form majority monolingualism through education. In this program the role of minority languages is limited to helping the learning of the second language. In the long run this model causes assimilation instead of integration (Skutnabb-Kangas 1990).

4. According to the Government's statute N1033 published in September 30, $2009^{10}$ in schools during working time only Ukrainian can be used. In case of minority language medium schools besides Ukrainian the language of instruction can be used too. It

8 The document entitled State programme for improving teaching the Ukrainian language in schools where the medium of instruction is a nationality language for the years of 2008-2011 is available in Ukrainian on the official website of the Ministry of Education and Science of Ukraine.

9 For the document see the official website of the Ministry of Education and Science of Ukraine: http://www.mon.gov.ua

${ }^{10}$ Постанова Кабінету Міністрів Украіни Про внесення змін до Положення про загальноосвітній навчальний заклад № 1033 від 30 вересня 2009 р. 
means that the Government endeavours not only to shift the language of instruction to Ukrainian but also to make peoples use the state language during the breaks too.

5. While the Ministry of Education quoted the very low level and low efficiency of the official language teaching in ethnic schools as the most important educational problem ${ }^{11}$, taking joint school leaving and entrance examinations in Ukrainian language and literature was made obligatory (statute N1171, dated December 25,2007$).{ }^{12}$ The exam is obligatory for all the applicants of higher education establishments, independently of what the person would like to be, a Ukrainian philologist, a historian, a chemist or a doctor. Exam requirements were absolutely the same for pupils from schools with Ukrainian as the language of instruction and pupils from ethnic schools. ${ }^{13}$ As a consequence of this in the year of introduction (2008) 8.38\% of school-leavers ${ }^{14}$ failed the Ukrainian examination (country average), while among pupils from Hungarian minority schools the ratio was $29.58 \% .{ }^{15}$ In the academic year 2009/2010 9\% of the applicants failed the exam in Ukrainian language and literature, nevertheless in an ethnically mixed region, Transcarpathia this ratio was $15 \%$. Beginning with the 2009/2010 academic year, all the joint school leaving and entrance examinations should be taken in Ukrainian in the country. ${ }^{16}$ According to point 7.2 of the ministerial decree N33 published on January 24, $2008^{17}$ examination tests are prepared in Ukrainian language in all the subjects; for pupils of ethnic schools the examination material will be translated in the transition period (in 2008 and in 2009) with

11 The Minister of Education stated the following in his speech held on March 4, 2008: "It has turned out that instead of teaching the Ukrainian language, very often they just imitate doing it, nevertheless the best marks were put in the certificates." http://www.mon.gov.ua/newstmp/2008/05_03/doc.doc

12 Наказ Міністерства освіти і науки Украйни Про зовнішне незалежне оцінювання навчальних досягнень випускників навчальних закладів системи загальної середньої освіти, які виявили бажання вступати до вищих навчальних закладів у 2008 роиі № 1171 від 25.12.2007 p.

13 I. Likarchuk, the leader of the centre for independent assessment in his letter (written in Ukrainian) N01/10-661 dated July 17, 2008 to the president of the Transcarpathian Hungarian Teachers' Organization proclaimed that the state requirements in the subject Ukrainian language and literature are the same for pupils of Ukrainian or ethnic Hungarian schools.

14 See: http://www.testportal.gov.ua

15 See in the newspaper Kárpátalja (June 6, 2008) 
the exception of the test in Ukrainian language and literature. ${ }^{18}$ From the year 2010 translation will not be allowed.

6. In Ukraine minority languages are also present in higher education; however the current education policy endangers their position too. The Minister of Education in his speech at the meeting of the leaders of higher educational institutions held on March 21, 2008 said (my translation): "One of the most important tasks of the Ministry of Education and Science is the wholesale introduction of state language education in higher educational institutions". ${ }^{19}$ As a part of this process the Ministry required the higher educational institutions to provide statistics about the number of courses which are taught in the institution according to degree programmes, and within this, how many are taught in Ukrainian and how many are taught in other languages. If there are courses that are not taught in the state language, reasons should be provided. On the bases of the received data on December 25, 2008 the Minister of Education wrote an official letter (N19/9-480) to all higher education establishments and established that the language of instruction partially or totally is not

16 According to the declaration written in the website of The Ministry of Education and Science of Ukraine: 'In the transmission period (years of 2008, 2009) the content of tests (with the exception of the test in Ukrainian language and literature) will be translated to some of the minority languages. http:// www.mon.gov.ua /main.php?query=newstmp/2008/20_03/).

Added by the authors: In the letter of the ministry N2/2-14-2717 dated August 8, 2008 sent to the Regional Committee of Beregovo it is also written that according to the decision of the government questions of school-leaving and at the same time entrance examinations will be translated to minority languages only in the 2008/2009 academic year.

${ }^{17}$ Наказ Міністерства освіти і науки Украӥни Про затвердження Порядку проведення зовнішнього незалежного оцінювання навчальних досягнень випускників навчальних закладів системи загальної середньої освіти № 33 від 24.01.2008 p.

${ }^{18}$ The same is repeated in the description of the order of school-leaving and entrance examinations in the year of 2009 (point 7.2.), which was affirmed by the ministerial decree N133 on March 13, 2009: Наказ Міністерства освіти і науки України Про затвердження нормативно-правових актів щуодо проведення зовнішнього незалежного оцінювання навчальних досягнень випускників навчальних закладів системи загальної середньої освіти в 2009 роиі № 133 від 18.03.2009 p.

19 The speech can be found in Ukrainian at: http://www.mon.gov.ua/ main.php?query=newstmp/2008/21_03 
Ukrainian in several institutions of the country. Referring to the Bologna Declaration and the European Higher Education Area, moreover, to the integration and mobility of the Ukrainian students he advised to the universities to make steps in order to foster that higher education in Ukraine became more and more Ukrainian. For example one of the Minister's advices is that those teachers who did not teach in Ukrainian (but mainly in Russian) hitherto should work as guest teachers for a shorter or longer period at universities where the language of instruction is Ukrainian. In exchange the home university should receive guest lecturers who teach their subjects in Ukrainian. The leader of the Ministry suggests the exchange and rotation of the students as well. According to this, students of universities where the medium of instruction is not Ukrainian should be sent to trainings (lasting for several months or a semester) at universities where subjects are taught in Ukrainian. The author of the letter stimulates teachers to gradually start working out their notes and books in Ukrainian; moreover, in the second semester beginning in February 2009 they could try to teach some of the subjects in Ukrainian. Further on the Minister of Education issued a decree N 341 on April 17, 2009 in order to improve the education of Ukrainian technical terminology. According to the document with the beginning of the academic year 2009/2010 the subject 'Ukrainian technical terminology' becomes one of the obligatory subjects in all higher education institutions in Ukraine, so teaching of it is also obligatory for all of the faculties (point 2.4). The subject should end with a state examination (point 1.5) and should be taught for foreign students who are studying in Ukraine, too (point 1.4).

In accordance with the above mentioned facts it is not surprising that in the draft version of the Law on Higher Education (worked out in spring 2008) Ukrainian appears as the only language of instruction in higher education..$^{20}$

Behind the above mentioned examples we can find the ideology of strengthening the importance and the value of the official

20 I. Likarchuk, the leader of the centre for independent assessment in his previously mentioned letter N01/10-661 dated July 17, 2008 stated that the entrance to the higher educational institutions happens on the basis of the results of the centre for independent assessment and in the institutions education is provided in the state language. In other words, according to the leader of the organization which is responsible for the arrangement of the school-leaving and entrance examinations higher education will be (or would be) Ukrainian even in the academic year 2008/2009. 
language. The state programme for improving the Ukrainian language in the years 2004-2010, which was also adopted by the government, proclaims: 'The Ukrainian language has a leading position in the state building process." In this document language appears as an important indicator of national identity. The standpoint of the Constitutional Court (accepted on April 22, 2008) is the following: "The status of the Ukrainian language as a state language is on the same level between the components of the constitutional order of the state as the territory, the capital and the symbols of the state."

The question why education and the medium of education has such an important role in the formation of the Ukrainian national consciousness, and in the process of shaping the desired homogeneous Ukraine can be answered with the help of some statistic data.

The European Charter for Regional and Minority Languages ratified by Ukraine in 2003 applies to the languages of 13 minority communities (see Beregszászi and Csernicskó 2004, 2007). Table 3 shows the coincidence of language identity, language maintenance and the language of instruction concerning the language of the majority (Ukrainians) and the above-mentioned 13 communities.

Table 3. Ethnicity, native language and the language of instruction data concerning larger ethnic communities in Ukraine.

\begin{tabular}{|c|c|c|c|c|c|}
\hline & \multirow[b]{2}{*}{ Number } & \multirow{2}{*}{$\begin{array}{l}\text { Percentage } \\
\text { within the } \\
\text { population } \\
\text { of Ukraine }\end{array}$} & \multirow{2}{*}{$\begin{array}{l}\text { Native } \\
\text { language } \\
\text { and ethnicity } \\
\text { are the same }\end{array}$} & \multicolumn{2}{|c|}{$\begin{array}{l}\text { The language of instruction } \\
\text { is one's native language }\end{array}$} \\
\hline & & & & $\begin{array}{l}\text { Number of } \\
\text { people }\end{array}$ & $\begin{array}{l}\text { How many } \\
\% \text { from all } \\
\text { of the pupils }\end{array}$ \\
\hline Ukrainian & 37541693 & 77.2 & 85.16 & 4379675 & 75.05 \\
\hline Russian & 8334141 & 17.28 & 95.92 & 1394331 & 23.89 \\
\hline Byelorussians & 275763 & 0.57 & 19.79 & - & - \\
\hline Moldavians & 258619 & 0.54 & 70.04 & 6508 & 0.11 \\
\hline Crimean Tatars & 248193 & 0.51 & 92.01 & 5945 & 0.10 \\
\hline Bulgarians & 204574 & 0.42 & 64.15 & 120 & 0.00 \\
\hline Hungarians & 156566 & 0.32 & 95.44 & 20229 & 0.35 \\
\hline Romanians & 150989 & 0.31 & 91.74 & 27471 & 0.47 \\
\hline Poles & 144130 & 0.30 & 12.95 & 1404 & 0.02 \\
\hline Jews & 103591 & 0.21 & 3.10 & - & - \\
\hline Greeks & 91548 & 0.19 & 6.37 & - & - \\
\hline Germans & 33302 & 0.07 & 12.18 & - & - \\
\hline Gagauses & 31923 & 0.07 & 71.49 & - & - \\
\hline Slovaks & 6397 & 0.01 & 41.16 & 97 & 0.00 \\
\hline
\end{tabular}


Table 3 demonstrates that language shift is at an advanced stage in the case of communities which do not have native language schools. In spite of the fact that Byelorussians are the second largest minority (after the Russians) in Ukraine, there are no schools with Byelorussian as the language of instruction and only $19.79 \%$ of them claim that their ethnicity is the same as their native language. In contrast to the Byelorussians, the Romanians and the Hungarians, for instance, are devoted both to their language and schools. It is, of course, not easy to decide that the high number of people who maintain their own language has coincidence with the fact that they can learn in their own language or they are devoted to their schools because their attitudes towards maintaining the language are strong. However, it could be probable that the two indicators correlate and strengthen each other.

Concerning the above-mentioned data, it is not surprising that the Ukrainian state thinks that citizens could be made Ukrainian monolingual speakers by reducing the number of schools with minority languages used as medium of instruction and by increasing the number of those pupils who get education in Ukrainian. These efforts aim to reach the Ukrainification of the Russian-dominant eastern and southern parts of the country.

The use of educational policy with the aim of assimilation is strengthened by the Ukrainian nation's own experiences. In the age of the Soviet Union, in the eastern and southern parts of the former USSR (Ukrainian Soviet Socialist Republic) there was hardly any school where the language of instruction was Ukrainian. Large numbers of Ukrainian pupils learned in schools where Russian was the language of instruction. This could be one of the reasons why only $40 \%$ of the Crimean people, $41 \%$ of the people in the county of Donetsk, and $50 \%$ of the people in the county of Luhansk claimed Ukrainian as their native language. ${ }^{21}$

In light of the developments in education, language and minority policy in the recent past, it seems clear that the Ukrainian elite, which in 1991 became a national majority from a Soviet minority, continues the inherited Leninist policies and methods towards ethnic minorities.

The essence of this kind of policy is to ensure broad rights for the minorities. Meanwhile it is suggested to them that minorities can be successful if they choose schools with Ukrainian as the

21 See census data on the website http://www.ukrcenzus.gov.ua 
medium of instruction, and if eventually they shift from their own language to Ukrainian. Namely, the state regards assimilation as the way of minority integration.

In this system the role of the minorities is that they can wear their national costumes at folklore festivals, they can sing their own songs, dance their traditional dances, perhaps attend their own churches and cook their national meals. But as soon as they enter a state office, their workplace or their schools, they should (possibly spontaneously) switch to Ukrainian.

Thus, Ukraine, instead of fostering the present-day ethnic and linguistic diversity, pursues the state model that is colorful from the ethnic point of view but homogeneous linguistically (in particular Ukrainian monolingual). After Russification which was disguised as Soviet internationalism, now the decade of Ukranification is coming disguised as democratic multiculturalism.

\section{Address:}

István Csernicskó

Kossuth sq. 6

90202 Beregszász

Ukraine

E-mail: csistvan@kmf.uz.ua

\section{References}

Arel, D. and V. Khmelko (1996) „The Russian factor and territorial polarization in Ukraine." The Harriman Review 9, 1-2, 81-91.

Beregszászi, A. and I. Csernicskó (2003) „Die Möglichkeiten des Gebrauchs der ungarischen Sprache in der Karpatoukraine de jure und de facto". In F. Glatz, ed. Die Sprache und die kleinen Nationen Ostmitteleuropas, 101-117. Budapest: Europa Institut Budapest.

Beregszászi, A. and I. Csernicskó (2004) „Az anyanyelvet nem megőrizni, hanem használni kell! A regionális vagy kisebbségi nyelvek Európai kartája és a kárpátaljai magyarság”. [Mother tongue should not be reserved but should be used! The European Charter for Regional and Minority Languages and the Transcarpathian Hungarians.] In: A. Beregszászi and I. Csernicskó, eds....itt mennyit ér a szó? Írások a kárpátaljai magyarok nyelvhasználatáról, 23-24. Ungvár: PoliPrint. 
Beregszászi, A. and I.Csernicskó (2007) “A regionális és kisebbségi nyelvek Európai kartája - ukrajnai módra”. [The European charter for regional and minority languages - the Ukrainian interpretation.] Kisebbségkutatás 2, 251261.

Berezovenko, A. (2002) „Between nation and state: Ukrainian identity in today's language reality". In R. Göbner and A. Kratochvil, eds. Ukrainische Kultur im europäischen Kontext, 143-144). Greifswald: University of Greifswald.

Bilaniuk, L. (2003) "Gender, language attitudes, and language status in Ukraine”. Language in Society, 32, 47-78.

Bilaniuk, L. (2004) „A typology of Surzhyk: mixed Ukrainian-Russian language”. International Journal of Bilingualism 8, 4, 409-425.

Bilaniuk, L. (2005) Contested tongues: language politics and cultural correction in Ukraine. Ithaca and London: Cornell University Press.

Gritsenko, O., V. Podkopaev, M. Strikha, V. Solodovnik, O. Chikalenko, O. Riznyk, and M. Kushnariova (2001) Multiculturalism and education: perspectives for introduction of multicultural principles in the system of secondary education in Ukraine. Analytic review and recommendations. Kiev: Ukrainian Center for Cultural Studies.

Khmelko, V. (Хмелько, В.) (2004) “Лінгво-етнічна структура України: регіональні особливості й тенденції змін за роки незалежності”.[ Linguistic and ethnic structure of Ukraine: regional differences and changing tendencies since the independence.] Naukovi zapysky NaUKMA. Socioligichni nauky 32, 3-15. http://www.kiis.com.ua

Kotygorenko, V. (Котигоренко В.) (2007) Мовний аспект державної етнополітики в Україні [Lingustic aspects of the state ethnopolicy in Ukraine.] Strategichni priorytety 3, 137-146.

Lenets, К. (Ленець, К.) (2000) “Суржик”. [Surzhyk.] In В. Русанівський, О. Тараненко, М. Зяблюк, Є. Карпіловська, І. Вихованець, П. Гриценко et al.,eds. Украӥнська мова. Енциклопедія, 616. Kуіv: Vydavnyctvo im. M. P. Bazhana.

Lozinskyi, Robert (Лозінський, Роберт) (2006) Тенденції мовної ситуації в Україні. [Tendencies of the linguistic situation in Ukraine.] Visnyk L'vivskoho universytetu. Seria geografichna 33, 217-227.

Masenko, L. (Масенко, Л.) (2004) Мова і суспільство: постколоніальний вимір. [Language and society: postcolonial dimension.] Kyiv: KM Academia.

Molnár, J. (2004) “Kárpátalja lakosságának nyelvi összetétele a 2001-es ukrajnai népszámlálás adatai alapján”. [The linguistic content of the Transcarpathian population based on 2001 census data.] In A. Beregszászi and I. Csernicskó, eds. Tanulmányok a kárpátaljai magyar nyelvhasználatról, 119-130. Ungvár: PoliPrint. 
Panina, N. (Паніна, Н.) (2005) Украӥнське суспільство 1994-2005: соиіологічний моніторинг. [The Ukrainian society between 1994-2005: sociological monitoring.] Kyiv: Institut siciologii NAN Ukrainy - Fond „Demokratychni iniciatyvy”.

Radchuk, V. (Рядчук, В.) (2002а) “Мова в Україні: стан, функції, перспективи". [Language in Ukraine: situation, functions, perspectives.] Dyvoslovo 2, 540, 2-5.

Radchuk, V. (Рядчук В.) (2002b) “Мова в Україні: стан, функції, перспективи". [Language in Ukraine: status, functions, perspectives.] Movoznavstvo 2-3, 39-45.

Skutnabb-Kangas, T. (1990) Language, literacy and minorities: a minority rights group report. London: The Minority Rights Group.

Kokkuvõte. István Csernicskó: Ukraina hariduspoliitika keeleteaduslikud aspektid. Vastavalt ukraina keeleseaduse konstitutsioonile (de jure) on Ukraina ükskeelne riik. Siiski on Ukraina (de facto) mitmekeelne. Ukraina riigikeele poliitika tahaks juriidiliselt kehtestatud ja tegelikkuse vahelist lahknevust lahendada selliselt, et Ukraina keeleline olukord ühtlustataks kodifitseeritud seadusliku olukorraga. Kuigi sellest ei räägita, tahetakse Ukraina muuta ükskeelseks, s.o (de facto) ukraina keelt rääkivaks riigiks. Hariduses nähakse ideaalset abivahendit niisuguste eesmärkide saavutamiseks. Käesolevas artiklis toetavad viimase väitekehtivust mitmed asjaolud. Selle asemel et soodustada tänapäevast etnilist ja keelelist mitmekesisust, jätkab Ukraina riikliku mudeliga, mis on küll mitmekesine etnilisest seisukohast, kuid keeleliselt homogeenne. Andmed, mida siinses uurimuses esitletakse, toovad esile selle, et nimetatud protsessiga kaasnevad suured kaotused ka Ungari vähemustele TagaKarpaatias.

Märksõnad: Ukraina keelepoliitika, hariduspoliitika, ungarlased TagaKarpaatias 
